\title{
RESEARCH NOTE
}

\section{COMPARISON OF GROWTH AND DEVELOPMENT OF SUGARCANE BORER LARVAE FROM PUERTO RICO AND LOUISIANA}

A basic wheat-germ diet developed by Adkisson et al. $(1960)^{1}$ for rearing the pink bollworm Pectinophora gossypiella (Saund.) has been used by workers in the United States to rear the sugarcane borer Diatraea saccharalis (F.) in the laboratory. Wongsiri and Randolph (1962) ${ }^{2}$ and more recently, workers at Louisiana State University have utilized this diet or slight modifications of it successfully to rear large numbers of sugarcane borer larvae for research purposes.

Walker et al. (1966) ${ }^{3}$ state that they have not been able to rear the sugarcane borer in Puerto Rico on diets developed for that purpose by workers in the United States. They attribute their lack of success to "strain" differences between borer populations there and in the United States. Results from studies in which growth and development of larvae from populations collected from Puerto Rico and Louisiana were compared are presented herein.

Approximately 100 sugarcane borer pupae that had been collected from sugarcane in several localities in Puerto Rico were brought to Baton Rouge and confined in an insectary for purposes of establishing a laboratory population. About 1,700 newly hatched larvae from this colony were transferred individually to shell vials containing wheat-germ diet. For purposes of comparison, 1,700 larvae from a sugarcane borer colony collected from sugarcane in South Louisiana were treated similarly. A comparison of growth and development of these larvae in the laboratory is presented in table 1. Results from rearing progeny from crosses of the two parental colonies in a similar manner are shown in table 2.

No significant differences were found between the two populations in their response to the laboratory rearing procedure and diet. Larvae from the Puerto Rico population developed and pupated or died at about the same rate as those from the Loufisiana population, and there was little difference in average weight of pupae between the two groups. Furthermore, when crosses were made between parental stock from each colony, there were no significant differences in larval development, survival, or

${ }^{1}$ Adkisson, P. L., Vanderzant, E. S., Bull, D. L., and Allison, W. E., A wheat germ medium for rearing the pink bollworm, $J$. Econ. Entomol. 58 (5): 759-62, 1960.

2 Walker, David W., Alemañy, A., Quintana, V., Padovani, F., and Hagen, K. S., Improved xenic diets for rearing the sugarcane borer in Puerto Rico, J. Econ. Entomol. 59 (1): 1-4, 1966.

${ }^{8}$ Wongsiri, T., and Randolph, N. M., A comparison of the biology of the sugarcane borer on artificial and natural diets, $J$. Econ. Entomol. 65 (4): 472-3, 1962. 
TABLE 1.-Comparison of development and survival of sugarcane borer larvae from Puerto Rico and Louisiana reared on a wheat-germ diet, Baton Rouge, La. in 19661

\begin{tabular}{l|c|c}
\hline \multicolumn{1}{c|}{ Item } & \multicolumn{2}{c}{ Source of parental stock } \\
\cline { 2 - 3 } & Puerto Rico & Louisiana \\
\hline Larvae reared & 1710 & 1700 \\
Percent pupation & 67.7 & 66.5 \\
Percent larval mortality & 31.7 & 33.2 \\
Average length of larval life-span (days) & 31 & 32 \\
Weight of pupae (mg.) & & 105.5 \\
Males (number) & 102.6 & 170.1 \\
Females (number) & 171.1 & \\
\hline
\end{tabular}

1 Study started May 13, 1966 and terminated July 10, 1966.

2 Numbers are averages of 40 pupae.

TABLE 2.-Comparison of development and survival of sugarcane borer larvae from different parental crosses, Baton Rouge, La. in $1966^{1}$

\begin{tabular}{|c|c|c|c|c|}
\hline \multirow[b]{2}{*}{ Item } & \multicolumn{4}{|c|}{ Parental cross } \\
\hline & $\begin{array}{c}\text { Puerto Rico } \\
\text { males X } \\
\text { Puerto Rico } \\
\text { females }\end{array}$ & $\begin{array}{c}\text { Puerto Rico } \\
\text { males } X \\
\text { Louisiana } \\
\text { females }\end{array}$ & $\begin{array}{c}\text { Louisiana } \\
\text { males } \times \\
\text { Puerto Rico } \\
\text { females }\end{array}$ & $\begin{array}{c}\text { Louisiana } \\
\text { males } x \\
\text { Louisiana } \\
\text { females }\end{array}$ \\
\hline Number of larvae reared & 200 & 200 & 200 & 200 \\
\hline Percent pupation & 80.5 & 77.0 & 74.5 & 86.5 \\
\hline Percent larval mortality & 17.0 & 19.5 & 22.0 & 10.5 \\
\hline Average length of larval period (days) & 37 & 35 & 38 & 34 \\
\hline \multicolumn{5}{|l|}{ Weight of pupae ${ }^{2}$ (mg.) } \\
\hline Males (number) & 106.5 & 109.7 & 104.6 & 108.5 \\
\hline Females (number) & 172.5 & 178.5 & 172.6 & 172.0 \\
\hline
\end{tabular}

1 Study started July 2, 1966 and terminated August 17, 1966.

2 Numbers are averages of 40 pupae.

weight of pupae among the progeny. These data indicate that there is little reason to assume that strains of the sugarcane borer differing in their nutritional requirements occur in Louisiana and Puerto Rico.

\author{
S. D. Hensley \\ Department of Entomology \\ Louisiana State University \\ L. F. Martorell \\ Department of Entomology
}

